\title{
WestVirginiaUniversity
}

THE RESEARCH REPOSITORY @ WVU

West Virginia Agricultural and Forestry Experiment

Davis College of Agriculture, Natural Resources

Station Bulletins

And Design

$1-1-1938$

\section{Control of cherry leaf-spot in West Virginia}

F.J. Schneiderhan

Follow this and additional works at: https://researchrepository.wvu.edu/ wv_agricultural_and_forestry_experiment_station_bulletins

\section{Digital Commons Citation}

Schneiderhan, F. J., "Control of cherry leaf-spot in West Virginia" (1938). West Virginia Agricultural and Forestry Experiment Station Bulletins. 288.

https://researchrepository.wvu.edu/wv_agricultural_and_forestry_experiment_station_bulletins/289 @ WVU. It has been accepted for inclusion in West Virginia Agricultural and Forestry Experiment Station Bulletins by an authorized administrator of The Research Repository @ WVU. For more information, please contact ian.harmon@mail.wvu.edu. 
West Virginia University Libraries

In|m
$30802 \quad 1005212247$ 



\title{
Control of Cherry Leaf-Spot in West Virginia
}

\author{
by F. J. Schneiderhan
}

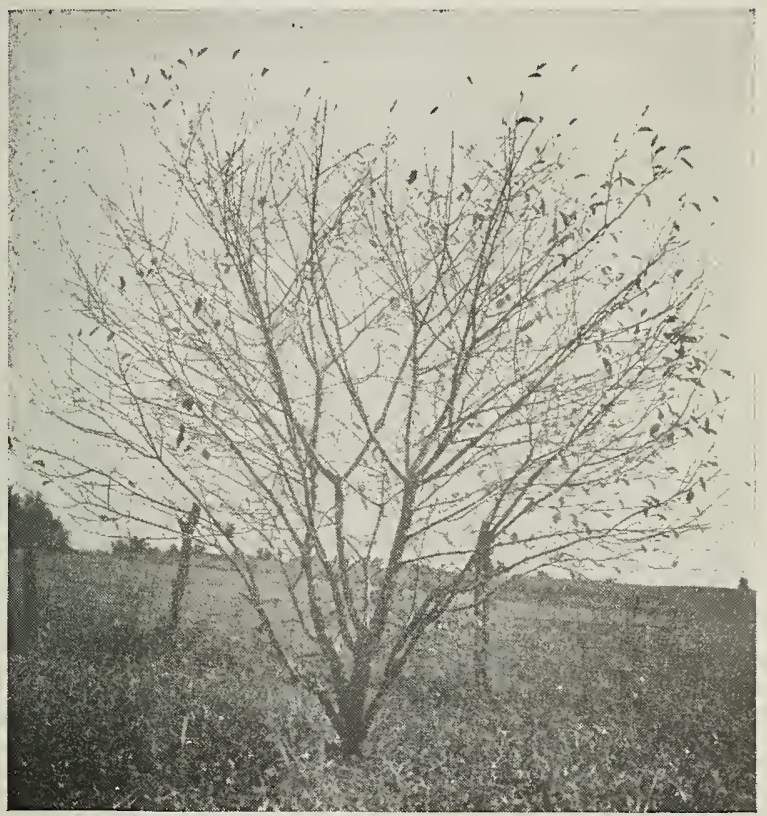

Cherry leaf-spot caused complete defoliation of this tree in July. Crop reduction, weak bud formation, and predisposition to winter injury follow premature defoliation

\section{Agricultural Experiment Station}

College of Agriculture, Forestry, and Home Economics.

West Virginia University

C. R, Orton, Director

Morgantown 


\title{
Agricultural Experiment Station StafF
}

\author{
C. S. BOUChER, Ph. D., LL. D., President of the University
}

C. R. ORTON, Ph. D.

Dean and Director

JOHN C. JOHNSTON, Chief Clerk......... CERALD JENNY, M. S., Agricultural Editor

\section{ACRONOMY AND CENETICS}

G. G. Pohlman, Ph. D., Head of Dept. W. M. Broadfoot, M. S., Asst. in Agron. C. R. Burnham, Ph. D., * Assoc. Gen. J. L. Cartledge, Ph. D., Asst. Gen. T. C. Mcllvaine, Ph. D., ${ }^{*} \dagger$ Assoc. Agron. J. A. Rigney, M. S., Asst. in Agron.

E. H. Tyner, Ph. D., Asst. Agron.

\section{ANIMAL HUSBANDRY}

E. A. Livesay, D. Sc., Head of Dept. M. L. Buchanan, M. S., Asst. in An. Husb.

T. B. Clark, M. S., Asst. Poult. Husb.

J. H. Longwell, A. M., Asst. An. Husb.

E. N. Moore, D. V. M., Asst. An. Path.

J. H. Rietz, D. V. M., An. Path.

E. T. Wightman, M. S., Asst. Poult. Husb.

C. V. Wilson, M. S., Assoc. An. Husb.

\section{CHEMISTRY}

R. B. Dustman, Ph. D., Head of Dept.

I. J. Duncan, Ph. D., Asst. Chem.

A. H. VanLandingham, Ph. D., Asst. Chem.

C. E. Weakley, Jr., M. A., Assoc. Chem.

\section{DAIRY HUSBANDRY}

H. O. Henderson, Ph. D., Head of Dept.

R. A. Ackerman, M. S., $\ddagger$ Asst. Dairy Husb.

G. A. Bowling, M. S., Assoc. Dairy Husb.

W. C. Brown, Ph. D., Asst. in Dairy Husb.

L. J. Manus, M. S., Asst. in Dairy Husb.

\section{ENTOMOLOGY}

L. M. Peairs, Ph. D., Head of Dept. Edwin Gould, B. S., ${ }^{*} \dagger \dagger$ Assoc. Ent.

\section{ECONOMICS}

W. W. Armentrout, Ph. D., Head of Dep M. A. Abrahamsen, M. A., Asst. Agr. Ecor

F. D. Cornell, Jr., Ph. D., Assoc. Agl Econ.

Margaret Cross, B. S. H. E., Statistician

W. K. Lanham, B. S. Agr., Asst. in Ag1 Econ.

E. O. Leonard, B. S. Agr. Asst. in Ag] Econ.

Gertrude Lucas, A. B., Statistician

L. F. Herrmann, M. S., Asst. in Agl Econ.

E. C.. Weitzell, M. S.* Asst. Agr. Econ. FORESTRY

W. C. Percival, Ph. D., Head of Dept.

L. Besley, M. F., Assoc. For.

H. D. Erickson, Ph. D., Asst. For.

\section{HORTICULTURE}

R. S. Marsh, A. M., Head of Dept.

E. P. Brasher, M. S., Asst. in Hort.

W. H. Childs, M. S., Asst. in Hort.

A. P. Dye, M. S., Asst. in Hort.

R. H. Sudd's, Ph. D., Asst. Hort.

K. C. Westover, Ph. D., Assoc. Hort.

\section{PLANT PATHOLOGY}

C. R. Orton, Ph. D., Head of Dept. Anthony Berg, M. S., Assoc. Plant Patl Hazel C. Cameron, Assoc. Physiol.

Genevieve B. Clulo, M. A., Asst. in Plar Path.

L. M. Hill, M. S., Asst. in Plant Path.

L. H. Leonian, Ph. D., Mycol.

V. G. Lilly, Ph. D., Asst. Physiol.

C. F. Taylor, Ph. D., Asst. Plant Path.

*In cooperation with the U. S. Department of Agriculture, Washington, D. C.

t In charge of the Lakin Experiment Farm, Lakin, W. Va.

$\$$ ln charge of the Reymann Memorial Farms, Wardensville, W. Va.

t†ln charge of the University Experiment Farm, Kearneysville, W. Va. 


\section{ntrol of Cherry Leaf-Spot in West Virginia}

by F. J. Schneiderhan

\section{ERRATA}

Please observe the following corrections in your copy of this bulletin:

Legend under Figure 1 belongs under Figure 3, Page 6.

Legend under Figure 2 belongs under Figure 1, Page 4.

Legend under Figure 3 belongs under Figure 2, Page 5.

Agricultural Experiment Station

College of Agriculture, Forestry, and Home Economics

West Virginia University

C. R, Orton, Director Morgantown 



\title{
Control of Cherry Leaf-Spot in West Virginia
}

\author{
by F. J. SCHNEIDERHAN
}

\section{INTRODUCTION}

OMMERCIAL CHERRY GROWING is a comparatively new branch of fruit-growing in West Virginia. It began about 1927, since then approximately 35,000 cherry trees, mostly Montmorency, ave been bearing in the Eastern Panhandle counties. Most of nese trees are now producing commercial crops, the annual producon having been estimated at 1000 tons valued at approximately 100,000 .

The most important disease of cherries in West Virginia, as in ther states, is cherry leaf-spot, which causes heavy losses unless ontrolled by timely spraying. As in most ventures in growing new inds of fruit, the cherry growers in this state are not so well cquainted with the problem of disease control as they are with ne control of diseases and insect pests of the apple. This publicaon is intended to acquaint cherry growers with the basic facts bout the leaf-spot disease and to present certain data obtained rom experimental studies which affect the cherry spray program.

\section{DESCRIPTION OF THE DISEASE}

The first indication of the leaf-spot disease is in the form of mall purplish spots circular in shape. These spots enlarge to bout one-eighth inch in diameter and turn brown. Individual large oots maintain their circular shape except as they coalesce with thers, when an irregular spot results. Both small and large spots cequently develop a corky layer between the outer edge and the omparatively healthy adjacent leaf tissue. This causes the infected rea to drop out, leaving a round or a ragged hole commonly known s shot-hole (see Figs. 1 and 2). Disease lesions also occur on the cuit stems and on the fruit itself, but this occurrence is comparavely rare and of little importance.

When a leaf is severely infected, chlorosis or yellowing usually llows: invariably such leaves drop prematurely. Infection may e localized in half of a leaf; in this instance the infected half bemes chlorotic while the other half may remain green (Fig. 3). ot all cherry leaf-yellowing is caused by the leaf-spot fungus, nd defoliation is not always caused by the disease. Furthermore, frequently happens that leaves drop without first yellowing; but is is unusual, especially in midsummer.

Because of this yellowing and shot-hole appearance, the leafot disease is known in different parts of the United States as yellowleaf," "leaf blight," "yellows," "shot-hole disease," and eaf spot." 


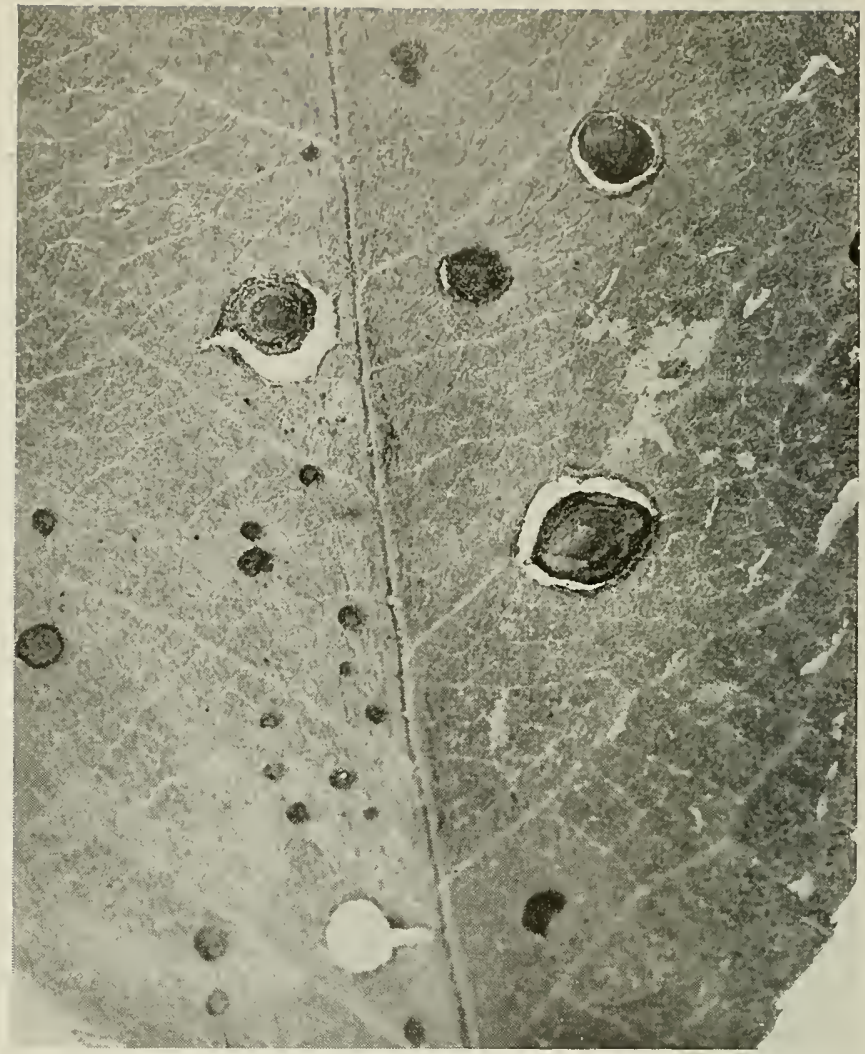

FIG. 1-Shot-hole stage of cherry leaf-spot

\section{Life CyCle of The CherRy LeAF-Spot Fungus}

The leaf-spot disease is caused by the fungus Coccomyce hiemalis, which overwinters in fallen leaves, becomes active in th spring shortly before the blooming period, and continues activ about two months longer. At the blooming period the winter spore (ascospores) mature in microscopic sacs (asci) and during rain are forcibly ejected into the air, which carries the spores to th leaves. Under favorable conditions of temperature and pal ticularly of moisture the spores germinate, forming a germ tub which penetrates the leaf tissue. Thus is established the fungu infection which, as mentioned, first manifests itself in the forr of small round purplish spots.

During periods of rain or prolonged high humidity, whitis spore masses form in the center of the enlarged leaf-spots, par ticularly on the lower leaf surface, where they are more numerous 
The leaf-spots appear to be blistered just before the rupture of the surface: this facilitates the oozing out of the spore masses made up of summer spores (conidia). Upon scattering and germinating, these spores cause secondary leaf-spot infection. Under West Virginia conditions infection by ascospores and conidia may be concurrent in June. During the late growing season, infection is spread only by conidia.
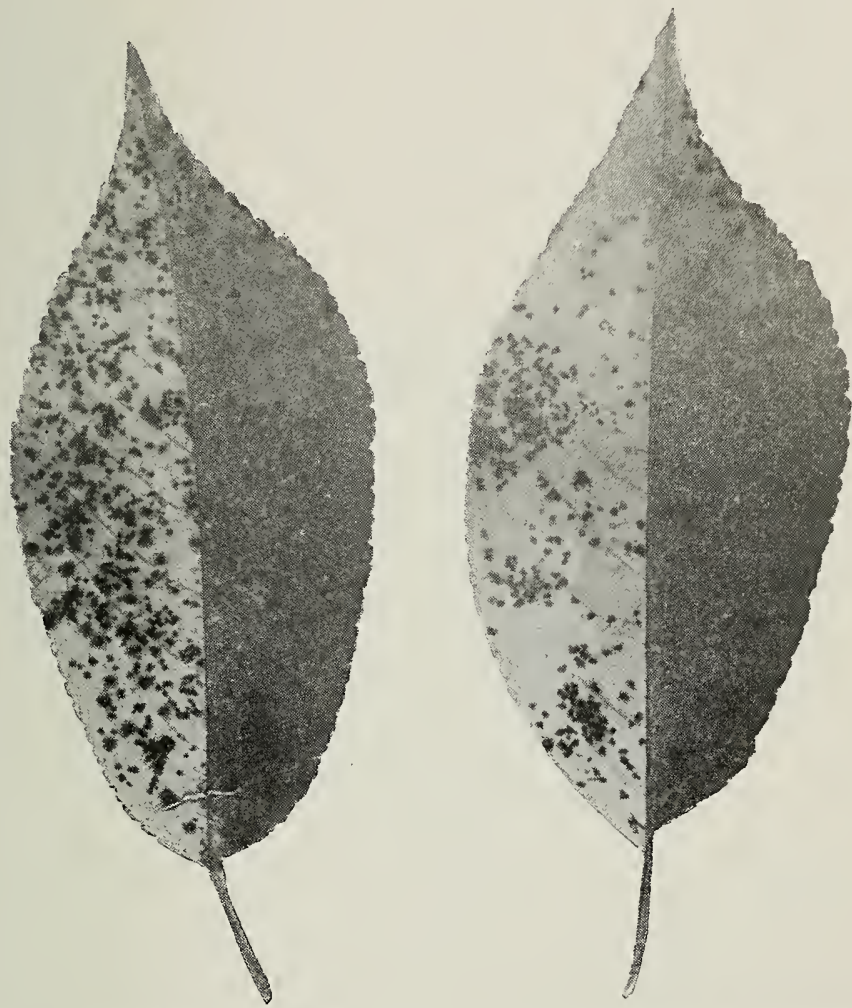

FIG. 2-Leaf-spot lesions partially and completely shot-holed.

Enlarged about 5 diameters

\section{The INJURY CAUSED BY CHERRY LEAF-SPOT}

Partial or complete defoliation of the trees is the most serious damage caused by this disease (Fig. 4). It is not uncommon to see cherry trees bearing more yellow than green leaves late in June just before harvest. Early defoliation usually follows heavy early infection and results in "small cherry," which seriously reduces the fruit yield. In addition, defoliation has an adverse effect on 
normal bud formation and thus affects the fruit crop of the follow. ing year. Devitalization of cherry trees following severe defoliatior predisposes such trees to insect and disease invasion, to winter injury, and to physiological disturbances in the years following.

According to Gloyer and Glasgow", "Where timely applications of fungicide were made so that leaf-spot was not a factor, there was a close relationship between defoliation due to yellow-leaf and winter injury of the roots" ... "In 1928, winter injury of the roots was associated with the epiphytotic of leaf-spot."

According to Roberts", "In mild cases only a few leaves may be injured, but frequently infections are so numerous that the tree is defoliated by midsummer. In such cases growth is interfered with and the tree becomes stunted and may be killed if defoliated through successive seasons or if otherwise in poor condition."

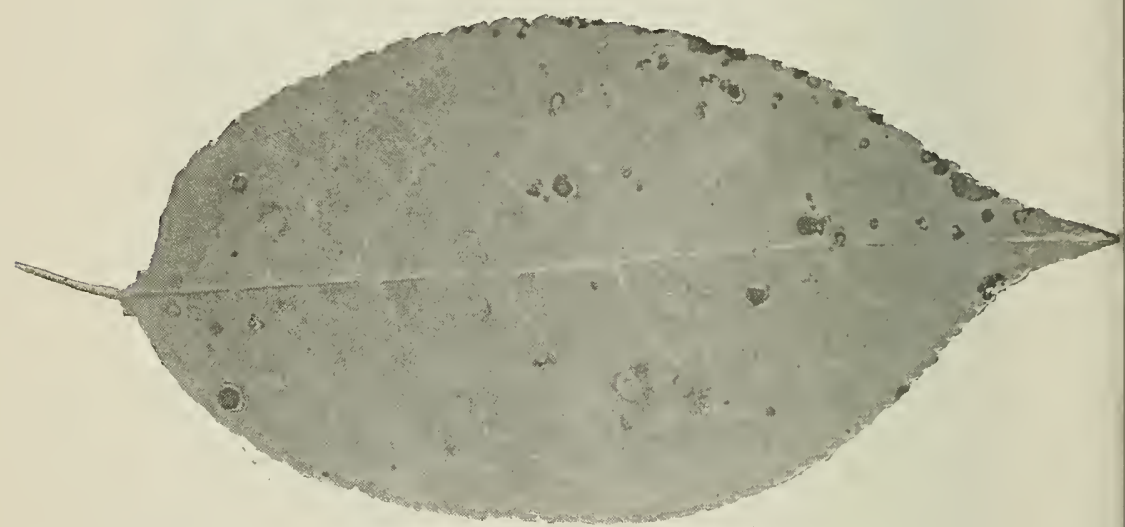

Frg. 3-Chlorosis or yellowing of cherry leaf. Note the localization of yellowing as shown in lighter areas and infection by leaf-spot

\section{EXPERIMENTAL PROCEDURE}

Experiments were begun in 1934 to establish an effective spray program for the control of cherry leaf-spot under conditions prevailing in the Eastern Panhandle counties of West Virginia. An effort was made to determine the relative value of each spray in the program used generally in 1934 and also the advisability of additional sprays. Ascospore discharges from infected leaves of the previous years were recorded to permit correlation, if possible, of

Gloyer. W. O., and Glasgow, Hugh. 1928. Defoliation of Cherry Trees in Relation to Winter lnjury. N. Y. State Agr. Expt. Sta. Bul. 555.

2 Roberts, John R. 1919. Control of Cherry Leaf Spot. U. S. D. A. Farmers' Bul, 1053:4. 
initial infection with timing of the early sprays. Lime-sulphur was used in the first three spray applications followed by flotation sulphur in the later sprays.

By following the method of omitting a certain spray application from a certain spray plot, as is shown in Table 1 , it is possible to evaluate each spray for the control of the disease.

TABLE 1-Outline of spray applications

\begin{tabular}{|c|c|c|c|c|c|c|}
\hline $\begin{array}{c}\text { Spray } \\
\text { application }\end{array}$ & $\begin{array}{c}\text { Plot } \\
1\end{array}$ & $\begin{array}{c}\text { Plot } \\
2\end{array}$ & $\begin{array}{c}\text { Plot } \\
3\end{array}$ & $\begin{array}{c}\text { Plot } \\
4\end{array}$ & $\begin{array}{c}\text { Plot } \\
5\end{array}$ & $\begin{array}{c}\text { Plot } \\
6\end{array}$ \\
\hline Pre-blossom & $X=$ apply & omit & $\mathrm{x}$ & $x$ & $\mathrm{x}$ & $\mathrm{X}$ \\
\hline Petal-fall & $\mathrm{x}$ & $\mathrm{x}$ & omit & $\mathrm{x}$ & $\mathrm{X}$ & $\mathrm{x}$ \\
\hline 1-week & $\mathrm{x}$ & $\mathrm{x}$ & $\mathrm{x}$ & omit & $\mathrm{x}$ & $\mathrm{x}$ \\
\hline 3-weeks & $x$ & $\mathrm{x}$ & $\mathrm{x}$ & $\mathrm{x}$ & omit & $\mathrm{x}$ \\
\hline Post-harvest & $\mathrm{x}$ & $\mathrm{x}$ & $\mathrm{x}$ & $\mathrm{x}$ & $\mathrm{x}$ & omit \\
\hline
\end{tabular}

In Plot 1 a full program of five sprays was applied. In Plot 2 the pre-blossom spray was omitted and in each of the other four plots one spray was omitted. Two check trees were selected in each of the six plots; each plot contained 25 trees of the Montmorency variety.

The spraying tests were made in the Lucas orchard* near Shepherdstown, W. Va. This orchard, planted in Montmorency trees, was about seven years old and in thrifty condition. Spray applications were made with two 4-nozzle brooms at a pressure of about 400 pounds.

\section{EXPERIMENTAL RESULTS}

\section{Ascospore Discharge-}

During 1934 and 1935, when a record of ascospore discharge was kept, the duration of the discharge period varied widely. In 1934 the supply of leaves used for spore trapping was limited, and the same leaves had to be used throughout the season. It is possible that sporulation was completed in this limited number of leaves before the normal time under natural conditions in the orchard.

In 1935 an abundant supply of infected leaves was available for spore trapping. The resulting record is considered to be more representative of the total length of the spore discharge period than the record of 1934.

Table 2, giving the data on ascospore discharge for 1934 and 1935, shows that in 1934 there were four ascospore discharges covering a period of 34 days between May 3 and June 6 . In this year the bud clusters were open; the white of the petals was showing on April 28. The development of the buds corresponded to the advanced pink-bud stage of apples. The full-bloom stage occurred May 2 to 4 and the petal-fall stage on May 14. It is evident from the record that one ascospore discharge occurred before the petal-fall

* The appreciation of the author is hereby expressed to A. Lucas for cooperating in these spraying experiments, which were performed in his orchard. 
TABLE 2-Dates of ascospore discharges of the cherry leaf-spot fungus Coccomyces hicmalis, from leaves of Montmorency, together with the rainfali in inches which caused these discharges. University Experiment Farm. Kearneysville, West Virginia, 1934 and 1935

\begin{tabular}{lclcc}
\hline & & & 1935 & \\
\hline Date of discharge & Rainfall & Date of discharge & Rainfall \\
\hline May 3.4 & 1.15 & April 30 & .28 \\
May 14 & .50 & May 2 & .58 \\
May 25 & .62 & May 6 & .42 \\
June 6 & .41 & May 7 & .60 \\
& & May 21 & .47 \\
& & May 30 & .28 \\
& & June 5 & .26 \\
& & June 6 & .20 \\
& & June 8 & .43 \\
& June 9 & .49 \\
& June 12 & .59 \\
\hline \hline
\end{tabular}

spray, this being the first spray recommended in West Virginia and in nearly every other cherry-growing state.

Table 2 shows also that in 1935 there were 14 discharges covering a period of 53 days between April 30 and June 21. In this year the bud clusters separated and showed white in the buds on April 18, the full-bloom stage occurred April 22 to 23, and the petal-fall stage on May 6. Since the heavy rains of May 6 and 7 prevented spraying, the petal-fall spray began on May 8 in most orchards. The record indicates four ascospore discharges in 1935 before the petal-fall spray.

The occurrence of ascospore discharges before the petal-fall spray is very significant, since, as previously stated, this spray has been the first spray recommended for leaf-spot in West Virginia. These data indicate that in both 1934 and 1935, infection was possible even before this spray.

TABLE 3-Dates of spray applications, and fungicide used

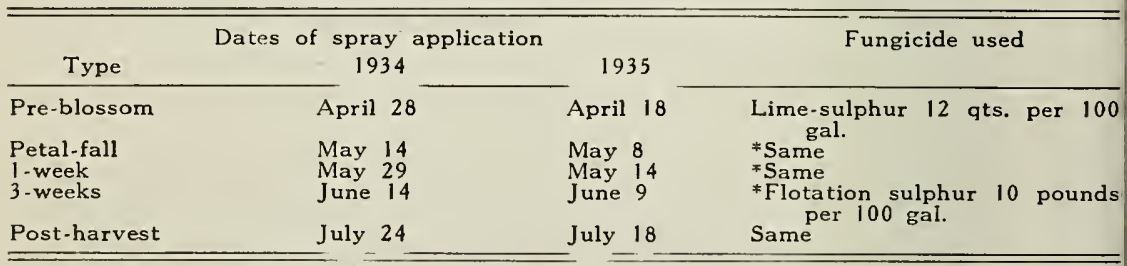

*In the petal-fall, 1-week, and 3-week sprays, lead arsenate, 2 lb. per 100 gal., was added for insect control.

In evaluating the data in Table 4, the cumulative effect of early infection is recognized. Other factors being equal, early infection would tend to accentuate the value of the early sprays in seasonal control of the disease. The percentage of control in all plots except 
The difference in the percentage of leaf-spot in the plots from which the pre-blossom spray was omitted in 1934 and 1935 is explained in part by the data in Table 2, which show that in 1934 there was only one ascospore discharge between the application of this spray and of the petal-fall spray, while in 1935 there were four discharges in this period.

Omission of the post-harvest spray in both years was followed by the heaviest leaf-spot infection in all the plots, the percentage of infection being 22 in 1934 and 90 in 1935. From the standpoin of early defoliation and crop reduction it is evident that the omission of the post-harvest spray cannot be a factor during the current year. It does appear, however, that this spray is the most effective of all sprays in controlling late infection and in decreasing the subsequent carry-over of the fungus to the next year.

In 1935 a much heavier infection occurred in all the spray plots than in 1934. This is likely the result of the unusual rainfall in June of 1935, when long, continuous rainy periods occurred. Although the total rainfall for the month was 3.21 in., which is 0.54 in. below normal, the weather record shows that rain fell on June $3,4,5,6,8$, and 9 . Another prolonged rainy period followed on June $15,16,17,18,19$, and 21 . Conditions for infection during these rainy periods were optimal, since the trees were continuously wet. The effect of these periods of rain is reflected in the incidence of leaf-spot in plots 4 and 5 , where the 1 -week and the 3 -weeks sprays were omitted, the percentage of infection being 50 in both plots.

\section{LATE-SEASON INFECTION}

The heaviest infection by cherry leaf-spot in the 4-year period 1934 to 1937 appeared during August and September even when all the sprays were applied. This observation would seem to emphasize the importance of the 3-weeks and post-harvest sprays. In 1935 a sudden appearance of the disease occurred early in August in the Station orchard at Kearneysville in spite of four spray applications, the last one having been made on July 14, ten days after harvest.

A record of the rate of increase in the number of leaf-spot lesions was made in this Montmorency orchard beginning on August 5. For this purpose twelve branches were selected on four different trees. All leaves except ten were stripped from the branches, and the count of lesions was made on 120 leaves at intervals of approximately six days. Table 5 , which shows the rate of increase in the appearance of new lesions over a period of 24 days indicates that after 5 days the number of leaf-spot lesions increased $38 \%$. After 11 days this increase was $69 \%$ and after 24 days it was $89 \%$. This rapid increase in infection late in the growing season was accompanied by chlorosis and leaf-dropping. No additional records were made after August 29, since a considerable number of the more heavily infected leaves had fallen. 
CABLE 5-Rate of increase in appearance of cherry leaf-spot lesions on leaves I Montmorency cherries, August 5 to 29 inclusive, Kearneysville, West Virinia, 1935

\begin{tabular}{|c|c|c|c|c|c|}
\hline \multirow[b]{2}{*}{$\begin{array}{l}\text { Branch } \\
\text { number }\end{array}$} & \multirow[b]{2}{*}{ Leaves } & \multicolumn{4}{|c|}{ Number of Lesions } \\
\hline & & Aug. 5 & Aug. 10 & Aug. 16 & Aug. 29 \\
\hline $\begin{array}{r}1 \\
2 \\
3 \\
4 \\
5 \\
6 \\
7 \\
8 \\
9 \\
10 \\
11 \\
12 \\
\end{array}$ & $\begin{array}{l}10 \\
10 \\
10 \\
10 \\
10 \\
10 \\
10 \\
10 \\
10 \\
10 \\
10 \\
10 \\
\end{array}$ & $\begin{array}{l}33 \\
64 \\
61 \\
64 \\
45 \\
38 \\
86 \\
21 \\
12 \\
12 \\
23 \\
22 \\
\end{array}$ & $\begin{array}{r}56 \\
89 \\
86 \\
78 \\
72 \\
40 \\
103 \\
49 \\
19 \\
16 \\
26 \\
31 \\
\end{array}$ & $\begin{array}{r}70 \\
100 \\
89 \\
87 \\
99 \\
61 \\
129 \\
52 \\
34 \\
25 \\
30 \\
38 \\
\end{array}$ & $\begin{array}{r}84 \\
109 \\
104 \\
87 \\
115 \\
73 \\
135 \\
52 \\
40 \\
30 \\
35 \\
44\end{array}$ \\
\hline Total & & 481 & 665 & 814 & 908 \\
\hline$\%$ Inc. & & & 38 & 69 & 89 \\
\hline
\end{tabular}

\section{SUMMARY}

Cherry leaf-spot is the most important disease of cherries in West Jirginia. Unless properly controlled it causes defoliation of trees, eduction in fruit yield, and devitalization of the trees, which prelisposes them to winter injury.

The fungus Coccomyces hiemalis, which causes cherry leaf-spot, verwinters in dead leaves and becomes active about blossom time, when it produces winter spores (ascospores), which cause early nfection. Summer spores (conidia) are formed in the leaf-spot esions and cause infection and spread of the disease later in the season. Ascospores and conidial infection may be concurrent.

Four ascospore discharges occurred between May 3 and June 6, 1934. In 1935 fourteen ascospore discharges occurred between April 30 and June 21. The record of spore discharges shows that nfection is possible before petal-fall spray, which has been the first spray hitherto used by West Virginia growers.

A pre-blossom spray has been indicated to be as valuable for leafspot control as the petal-fall spray, according to two years of experimental tests. The data showing the value of the pre-blossom spray in 1934 and 1935, although limited, nevertheless indicate the probability of recurring seasons in which this spray will give additional control of the disease. As insurance against early leaf-spot infection it is, therefore, suggested as an additional regular spray to the program used heretofore. The spraying experiments show that the post-harvest spray is relatively the most important spray in preventing late infection and heavy carry-over of the fungus.

During the 4-year period 1934-1937 inclusive, the heaviest leafspot infection appeared in August and September. This observation points to the necessity of a post-harvest spray. 
Orchard sanitation, particularly disking under of dead cherry leaves in the spring before spore discharge occurs, is suggested as supplement to thorough and timely spraying.

\section{Discussion OF THE SPRAy Program For CherRIES}

\section{Dormant Spray}

In young sour-cherry orchards the dormant spray is usually unnecessary because it takes time for San Jose Scale to become established. Scale infestation in most of the sour-cherry orchards is of minor importance; examination of the trees by the cherry grower should determine the advisability of applying this spray. I black-cherry aphis eggs are present, tar oil or some other proved ovicidal spray should be used.

\section{Pre-blossom Spray}

Although only two years of experimental data are available, the pre-blossom spray has given significant aid in the control of cherry leaf-spot. It is believed advisable, therefore, to recommend this additional spray because of its protection against the earliest infection.

\section{Petal-fall Spray}

It is considered advisable to begin the petal-fall spray wher. two-thirds of the petals have fallen and not to wait until imme. diately after all the petals have dropped. This is particularly necessary if wet weather should prevail during the latter part of the blooming period. The record of ascospore discharges in Table 2 verifies the recommendation to apply the petal-fall spray before al] the petals have fallen.

\section{The 10-day Spray}

Because of the rapid leaf growth following the blooming period: large areas of new leaf surface will be exposed to infection by ascospores unless they are properly protected by a fungicidal covering. This spray could be applied to better advantage from ten days to two weeks after petal-fall in order that the 3-weeks spray may be applied later than at present, which would make it more effective for the control of brown rot.

\section{The 3-weeks Spray}

In West Virginia, cherry picking usually begins during the week before July 1. According to Verner (3) the increase in weight of Montmorency cherries between June 23 and July 5 was $25.7 \%$; an increase of $1.8 \%$ occurred between July 2 and July 5 . This would seem to emphasize the value of delaying the beginning of picking until the latter part of the first week in July. This delay, although warranted, increases the suspectibility of the fruit to brown-rot infection, which appears suddenly and spreads rapidly especially if fruits are bruised by high winds or injured by birds in hot, humid

3 Verner, Leif, 1933. Time of Picking of Montmorency Cherries. W. Va. Agr. Expt. Sta. Mim. Circ. $6: 2-3$. 
eather. The 3-weeks spray is the only protection given for brown t unless a special spray for this disease is applied within a week , ten days before harvest. If no special brown-rot spray is applied, is advisable to delay the 3-weeks spray until a week to ten days efore harvest. In that event no lead arsenate should be used, and me proved wettable sulphur should be substituted for lime-sulphur ' prevent visible spray residue. Experience may eventually prove lat a special brown-rot spray is advisable.

\section{The Post-harvest Spray}

Both the experimental spraying tests and the observation that te infection is characteristic in West Virginia emphasize the ssolute necessity of applying a post-harvest spray. This spray lould be the most thorough of any in the program because it conols late infection thus preventing premature leaf drop and decreasig the carry-over of infected leaves to the next year.

\section{THE SPRAY PROGRAM FOR CHERRIES}

\begin{tabular}{llll}
\hline $\begin{array}{l}\text { o. of } \\
\text { sray }\end{array}$ & \multicolumn{1}{c}{$\begin{array}{c}\text { Time to } \\
\text { apply }\end{array}$} & \multicolumn{1}{c}{$\begin{array}{c}\text { To } \\
\text { Control }\end{array}$} & \multicolumn{1}{c}{$\begin{array}{c}\text { Spray materials for 100 } \\
\text { gal. of spray }\end{array}$} \\
\hline \hline $1^{* *}$ & Dormant season & $\begin{array}{l}\text { San Jose scale, } \\
\text { black cherry } \\
\text { aphid }\end{array}$ & $\begin{array}{l}\text { Lime-sulphur 121/2 gal. } \\
\text { Tar oil or other proved ovi- } \\
\text { cides according to directions } \\
\text { by manufacturers. }\end{array}$ \\
\hline 2 & $\begin{array}{l}\text { When bud clus- } \\
\text { ters open and } \\
\text { spread }\end{array}$ & Leaf-spot & $\begin{array}{l}\text { Lime-sulphur 12 qt. } \\
\text { (Use 10qt. for sweet cherries) }\end{array}$ \\
\hline 3 & $\begin{array}{l}\text { When 2/3 of } \\
\text { blossoms have } \\
\text { fallen }\end{array}$ & $\begin{array}{l}\text { Leaf-spot } \\
\text { Insects }\end{array}$ & $\begin{array}{l}\text { Lime-sulphur 12 qt. and } \\
\text { Lead arsenate 2 lb. }\end{array}$ \\
\hline 4 & $\begin{array}{l}\text { Ten days to two } \\
\text { weeks after No. } \\
3\end{array}$ & $\begin{array}{l}\text { Leaf-spot } \\
\text { Insects }\end{array}$ & $\begin{array}{l}\text { Lime-sulphur 12 qt. and } \\
\text { Lead arsenate 2 lb. }\end{array}$ \\
\hline $5^{*}$ & $\begin{array}{l}\text { Ten days pre- } \\
\text { vious to harvest }\end{array}$ & $\begin{array}{l}\text { Brown rot } \\
\text { Leaf-spot }\end{array}$ & $\begin{array}{l}\text { Lime-sulphur 12 qt. or some } \\
\text { proved wettable sulphur ac- } \\
\text { cording to directions of the } \\
\text { manufacturer }\end{array}$ \\
\hline 6 & $\begin{array}{l}\text { Immediately } \\
\text { after harvest }\end{array}$ & Leaf-spot & $\begin{array}{l}\text { Lime-sulphur 12 qt. or some } \\
\text { proved wettable sulphur. }\end{array}$ \\
\hline \hline
\end{tabular}

*If a special brown-rot spray is usually applied, Spray No. 5 may be applied earlier, out 3 weeks after No. 4.

** If no dormant spray for aphid control is applied, nicotine sulphate, I pint per 100 1., preferably in an alkaline medium like lime-sulphur or water plus hydrated lime, should applied heavily when aphids appear in considerable numbers. 
